\title{
DETERMINANT YIELD TO MATURITY OF BANKING SECTOR BONDS LISTED ON THE INDONESIA STOCK EXCHANGE FOR THE PERIOD 2015- 2020
}

\section{Elfira Riani Syamsu, Endri}

Mercu Buana University, Indonesia

Email: elfirariani24@gmail.com, endrifari@gmail.com

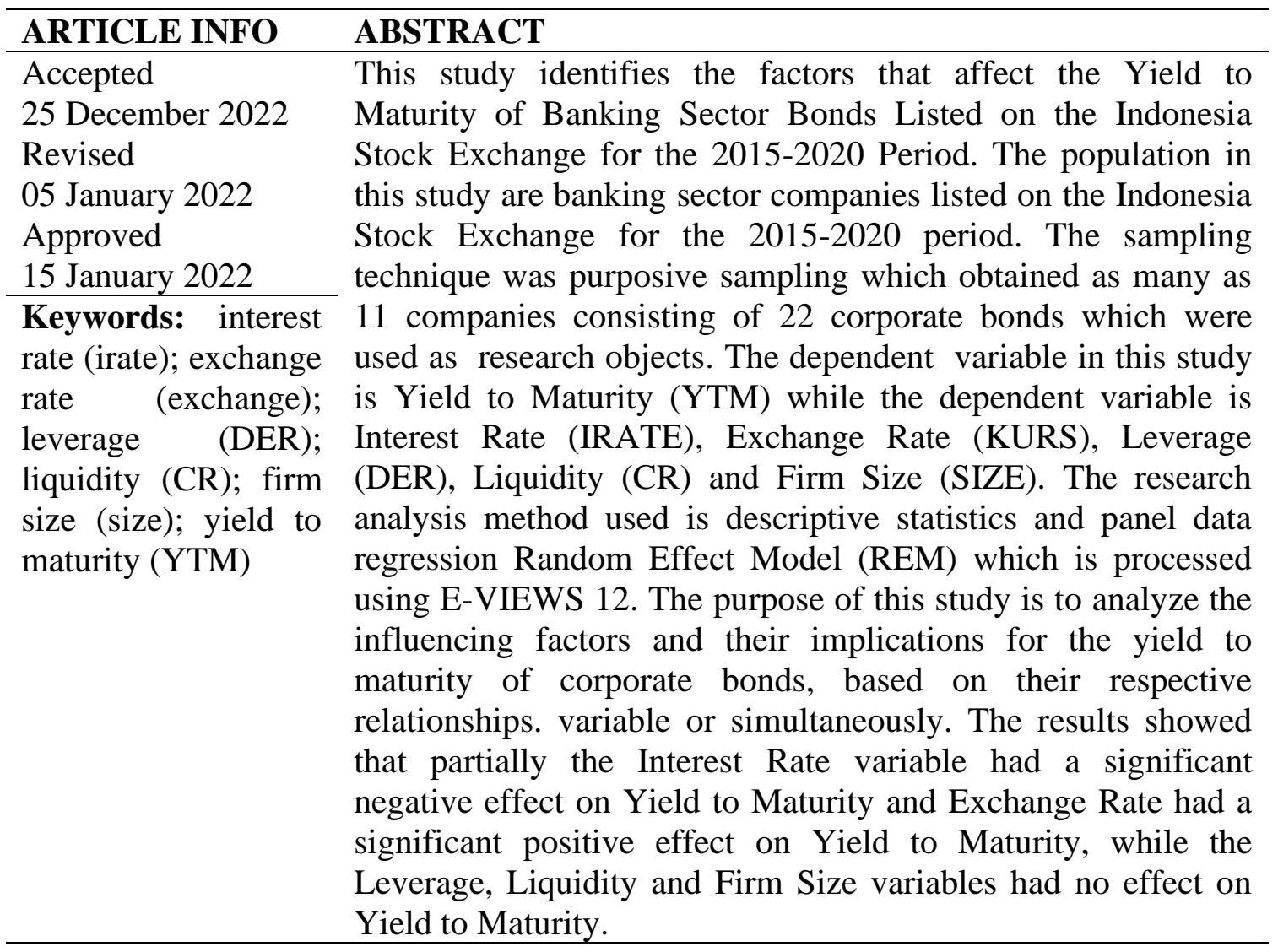

\section{Introduction}

Capital markets are activities related to the public offering and trading of public company securities related to the securities they issue, as well as institutions and professions related to securities. Capital market is a means of capital formation and accumulation of funds directed to increase public participation in the direction of funds to support national development financing. Currently the only capital market in Indonesia is the Indonesia Stock Exchange (IDX).

Capital markets can be an alternative to raising funds in addition to the banking system. The collection of funds through investments in the capital market, one of which is through bonds. For some investors bonds can be used as an alternative to long-term

$\begin{array}{ll}\text { How to cite: } & \text { Syamsu, E. R., Endri. (2022) Determinant Yield To Maturity of Banking Sector Bonds Listed On } \\ & \text { The Indonesia Stock Exchange For The Period 2015-2020. Jurnal Syntax Admiration 3(1). } \\ & \text { https://doi.org/10.46799/jsa.v3i1.369 } \\ \text { E-ISSN: } & 2722-5356 \\ \text { Published by: } & \text { Ridwan Institute }\end{array}$


investments other than stocks. Some things cause investors to be more interested in bond investments than stocks. First, the risk of losses that investors will receive is low because the income provided by bonds tends to be fixed (fix income) in the form of coupons paid every 3 months, 6 months or once every 1 year until the maturity time (Veronica, 2015). Second, bonds are safer than shareholders, because bond investors will take precedence in their refunds if a company goes into bankruptcy. This is because there is an agreement contract to pay it off (Zulfa \& Nahar, 2020).

There are two types of bonds: government bonds and corporate bonds. The difference between the two bonds lies in yield and risk. Corporate bonds are risky, but they are able to offer higher yields. While government bonds can be said to be zero risk, but yields and coupons are low. Investors choose corporate bonds because the yields offered are higher compared to government bonds.

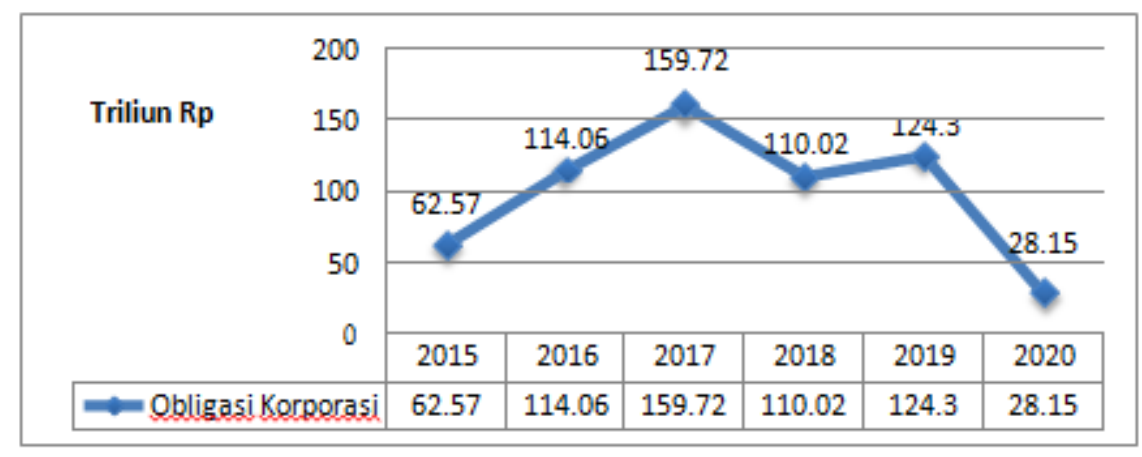

Figure 1

Corporate Bond Issuance Chart For The Period 2015-2020

Source: Indonesia Stock Exchange (IDX)

Based on figure 1 shows the issuance of corporate bonds fluctuating during the period 2015-2020. And it has a significant decline in 2020. Seen in 2018 bond issuance decreased $-31.12 \%$ which was originally in 2017 amounting to Rp. 159.72 trillion to Rp. 110.02 trillion in 2018 . And decreased again in 2020 by $-77.35 \%$ from Rp. 124.3 trillion in 2019 to Rp. 28.15 trillion in 2020.

In 2018 there was a decline because issuers chose to delay the issuance of bonds. High interest rates make bond issuers have to think again to provide yields or yields to investors because they consider the company's cost of fund. The high cost of funds makes companies eager to issue new bonds compared to waiting for a trend of interest rate hikes that look potentially up. This factor is due to the increase in the benchmark interest rate. Bank Indonesia five times raised its benchmark BI-7 Day Reverse Repo interest rate from 4.25\% in January 2018, 4.50\% in May 2018, 5.50\% in August 2018, $5.75 \%$ in September 2018 and 6.00\% in November 2018. (www.bi.go.id).

In 2020, the decline in the value of corporate bond issuance is inseparable from the effects of the COVID-19 pandemic. According to the Indonesia Stock Exchange (IDX) recorded the value of bank corporate bond issuance of around Rp. 7.88 trillion, reduced compared to the value of issuance in 2019 which reached Rp. 24.28 trillion. 
Declining publishing Corporate banking bonds are inseparable from relatively low credit growth so that banks experience adequate liquidity derived from the collection of Third Party Funds (DPK), so banks still issue minimal debt securities for liquidity needs. This is the first time this happens, because in the usually the issuance of financial sector bonds always dominate above 50\% every year (www.liputan6.com).

Low bond issuance due to high interest rates. High interest rates make bond issuers have to think again to provide yields or yields to investors because they consider the cost of funds. The trend shows that investor interest in corporate bonds, especially in the banking sector, is lower because the yield on maturity is low. This phenomenon is very interesting to analyze further about what factors affect corporate bond yields.

Yield is the most important factor as an investor's consideration in making bond purchases as an instrument of investment profit. Yield to Maturity is widely used because it reflects returns or returns with compound interest rates that investors expect. There are several factors that affect the yield to maturity of corporate bonds, namely external factors and internal factors of the company. External factors are macroeconomic factors such as interest rates, bond ratings and exchange rates. Internal factors are economic factors that occur in the internal company, such as the financial performance of the company i.e. leverage, liquidity and the size of the company itself. Investors who invest funds in the corporate bond market must be aware of the risk of bond issuing companies that are unable to fulfill predetermined promises, namely the risk of companies not being able to pay coupons or return bond principal (risk of default or risk of default).

Bank Indonesia's benchmark interest rate is a policy interest rate that reflects the stance of monetary policy set by Bank Indonesia and made public. Bank Indonesia's benchmark interest rate is one of the mechanisms used by Bank Indonesia to control the stability of the rupiah value (Nelmida, 2018). Bank Indonesia's benchmark interest rate is variable depending on the country's economy. Interest rates show a downward trend then bond prices move up this is because investors tend to prefer bond investments, conversely if interest rates tend to increase then bond prices will decrease because investors are more interested in storing funds in banks. The price of bonds that increase then the yield to maturity will decrease and vice versa, if the bond price decreases then the yield to maturity will increase.

Exchange rate variables have a positive and significant influence on yield variables. The higher the exchange rate, the higher the yield to maturity. If the rupiah exchange rate against the USD is high, the rupiah will depreciate. The company has debt in the form of USD so that the debt or maturity installments will increase the cost of capital or company expenses (Aulia and Miyasto, 2019).

Based on previous research conducted by (Nariman, 2016), (Ulfah et al., 2019) and (TRINH et al., 2020), stated that interest rates have a posotive effect on Yield to Marturity. Compared to research conducted by Friday E and (Nkwede et al., 2016) which states that interest rates negatively affect yield to marturity. It's on research (Megananda et al., 2021) stated that interest rates have no effect on Yield to Marturity. 
According to (Fabozzi \& Modigliani, 1995) the exchange rate is defined as the price of any domestic currency against another country's currency or in other words the price of a currency against another currency. An exchange rate is a representation of the exchange price level between currencies, used in international transactions and the flow of money between countries in the short term (Karim, 2014).

Based on previous research conducted by (Ernawati, 2019) Exchange rates have a positive effect on yield to maturity. (Ahmad \& Wahyudiani, 2019) stated that the exchange rate negatively affects yield to maturity. According to (Megananda et al., 2021) and Juliani, et al (2016) exchange rates have no effect on yield to maturity.

The leverage ratio is a ratio that investigates the extent to which companies use funding through debt (financial leverage). The leverage ratio is a ratio that indicates the level of proportion of debt usage in financing investments. In this study, leverage measurements used Debt to Ratio (DER). DER is the ratio of balance between debt owned by the company and its own capital. This ratio is useful to know the amount of funds provided by the borrower (creditor) to the owner of the company.

The higher this ratio means that the capital itself is less than the debt. Large companies that have high DER will offer low yields and vice versa for companies that have a low DER so offer high yields to attract investors to invest in bonds issued by the company. This indicates investors in making investments do not have to pay attention to the DER owned by the company and investors consider that the company issuing bonds has gone public so that investors are not too worried about the risk (Listiawati \& Paramita, 2018).

Research conducted by (Situmorang, 2017) states that leverage has a positive effect on Yield to Maturity. (Listiawati \& Paramita, 2018) and (Che-Yahya et al., 2016) stated that leverage negatively affects yield to maturity. But in contrast to research by (Latif \& Marsoem, 2019) states that leverage has no influence on YTM because the increase in leverage ratio does not affect the possibility of increasing bond yields, which means the leverage ratio is not taken into account in determining bond yields.

Corporate liquidity is an assessment of the company's ability to generate sufficient cash flow to meet all its obligations (Putri, 2013). The position or wealth of a company is also indicated by liquidity. In general, the level of liquidity is used as a benchmark as the company's decision making, especially within the company. The higher the level of liquidity of a company, the better the performance of a company. Companies that have a high level of liquidity will get a lot of support from outsiders such as investors and creditors in investing, so that the yield or yield to maturity that the company will give to its investors is higher (Ernawati, 2019).

Based on previous research conducted by (Ernawati, 2019) and (TRINH et al., 2020) stated that liquidity has a positive effect on yield to maturity. (Putri, 2013), (Oktavian et al., 2015) in their research liquidity has a negative impact on yield to maturity. Meanwhile, according to (Hamid et al., 2019) liquidity has no effect on yield to maturity. 
The size of a company is a scale that can be classified as small in various ways, among others: total assets, long size, market value of bonds or stocks, and others. Large companies tend to be safer than small companies that have considerable risk, because companies that have larger assets tend to have better competitive capabilities compared to companies that have smaller assets (Desnitasari \& Norita, 2014). Therefore, it becomes an attraction for investors in investing in the company. The size of the company can be measured using the total assets, sales, or capital of the company.

Based on previous research conducted by (Surya \& Nasher, 2011) and (Weniasti \& Marsoem, 2019) stated that the size of the company positively affects yield to maturity. According to (Yusniar \& Hadi, 2021) negatively affect yield to maturity. While (Situmorang, 2017) stated that the size of the company had no effect on yield to maturity.

Based on the description and phenomenon and the results of previous research, the author is interested in reviewing further on the "Determinant Yield to Maturity of Banking Sector Bonds Listed on the Indonesia Stock Exchange period 2015-2020".

\section{Method}

1. Research Design

This type of research design is causality research that aims to test hypotheses and find out the relationship and influence between two or more variables against other variables. This research aims to test the influence of independent variables, namely interest rates, exchange rates, leverage and the size of companies against dependent variables, namely yield to maturity.

2. Population and Sample

Population is a generalization area consisting of objects or subjects that have certain qualities and characteristics set by researchers to be studied and then drawn conclusions (Yani, 2017). The population in this study is the banking sector corporate bonds traded on the Indonesia Stock Exchange (IDX) during 2015-2020.

The sample is part of the number and characteristics of the population (Yani, 2017). Sampling in this study will use purposive sampling techniques, namely sampling techniques with certain considerations and criteria from researchers only that can be used as specific research samples (Yani, 2017).

3. Types and Methods of Data Collection

The type of data used in this study is quantitative data. Based on the source of the data used is secondary data with the type of panel data. It consists of cross section data (cross section) and time series data. The use of panel data in observation has several advantages: first, panel data which is a combination of two time series of data and cross-section can provide more data so that it will result in a greater level of freedom. Second, combining information from time series data and cross-sections can solve problems that arise when there the variable problem is eliminated. The data collection methods used in this study are as follows: 
4. Data Analysis Methods

Data obtained from the results of subsequent studies was analyzed with a regression model of panel data that aims to determine the effect of Interest Rates, Exchange Rates, Leverage, Liquidity and Corporate Size on Yield To Maturity of bonds. The study used panel data and data processing using EViews version 12 software. The significant rate set in the study was $\alpha=5 \%$ or 0.05 . This means that the probability of the correctness of the conclusion results has a probability of $95 \%$ or a $5 \%$ error tolerance.

\section{Results and Discussions}

\section{A. Result}

\section{Overview of Research Objects}

The object of this research is a banking sector company. The banking sector was chosen because the banking industry is an institution that has an important role in the growth of economic stability if the financial performance of a bank is in good condition then the bank will continue to gain the trust of the public. Through proper management of bond yields, banks can give the depositors confidence that they can take their funds at any time or at maturity. Therefore the bank must maintain its bond yields.

Banking sector companies that are objectified are companies listed on the Indonesia Stock Exchange (IDX) which has published annual reports and annual financial statements for the period 2015-2020. The sampling method used is a sampling technique with certain considerations and criteria from researchers that can be used as a sample of a particular study (purposive sampling). The total sample number used in the study was 11 banking sector companies with 22 series of bonds and 132 observational data studied. The following list of companies and series of bonds issued during the period 2015-2020 include:

Table 1

The Series of Bonds That Became the Object of Research

\begin{tabular}{ccl}
\hline No & $\begin{array}{c}\text { Bond } \\
\text { Series }\end{array}$ & \multicolumn{1}{c}{ Bond Series Name } \\
\hline 1. & BACA01SB & Subordinated Bonds of Bank Capital I Year 2014 \\
\hline 2. & BBIA01SB & Subordinated Bonds I Bank UOB Indonesia Year 2014 \\
\hline 3. & BBIA01C & Bank UOB Indonesia's 2015 Bond Seri C \\
\hline 4. & BBKP02SBCN1 & Sustainable Subordinated Bonds II Bank Bukopin Phase I 2015 \\
\hline 5. & BBRI01BCN1 & Sustainable Bonds I Bank BRI Phase I 2015 \\
\hline 6. & BBTN14 & XIV Bank BTN Bonds of 2010 \\
\hline 7. & BBTN15 & XV Bank BTN Bonds of 2011 \\
\hline 8. & BBTN01CN1 & Sustainable Bonds I Bank BTN Phase I 2012 \\
\hline 9. & BBTN01CN2 & Sustainable Bonds I Bank Btn Phase II 2013 \\
\hline 10. & BBTN02BCN1 & Sustainable Bonds II Bank BTN Phase I 2015 Series B \\
\hline 11. & BBTN02CCN1 & Sustainable Bonds II Bank BTN Phase I Year 2015 Series C \\
\hline 12. & BBTN02DCN1 & Sustainable Bonds II Bank BTN Phase I Year 2015 Series D \\
\hline
\end{tabular}




\begin{tabular}{ccl}
\hline 13. & BEXI02BCN4 & Indonesia Eximbank II Sustainable Bonds Phase IV Phase 2015 Series B \\
\hline 14. & BEXI02CCN5 & Indonesia Eximbank II Sustainable Bonds Phase. V 2015 Series C \\
\hline 15. & BEXI02CCN6 & Sustainable Bonds. Indonesia Eximbank II. Stage VI 2015 Series C \\
\hline 16. & BNGA02SB & Subordinated Bonds II of Bank CIMB Niaga in 2010 \\
\hline 17. & BNII02SBCN1 & Bank BII Phase I Sustainable Subordinated Bonds 2014 \\
\hline 18. & BNLI02SBCN1 & Sustainable Subordinated Bonds II Bank Permata Phase I 2013 \\
\hline 19. & BNLI02SBCN2 & Sustainable Subordinated Bonds II Bank Permata Phase II 2014 \\
\hline 20. & BVIC03SB & Bank Victoria III Subordinated Bonds of 2013 \\
\hline 21. & MAYA03SB & Subordinated Bonds of 2013 \\
\hline 22. & MAYA04SB & Subordinated Bonds of 2014 \\
\hline \multicolumn{3}{c}{ Source: Indonesian Central Securities Custodian (KSEI) }
\end{tabular}

\section{Descriptive Statistics}

Descriptive statistical analysis is a way of obtaining a thorough picture of the variables used in this study. free variables (independent) or bound variables (dependent). These descriptive statistics include mean and extreme values (maximum values and minimum values). Here are descriptive statistics of the variables used in the study :

Table 2

Descriptive Statistics Independent Variables and Dependent Variables

\begin{tabular}{lcccccc}
\hline & YTM & IRATE & Kurs & DER & CR & Size \\
\hline Mean & 0.215159 & 0.052083 & 9.537733 & 6.184280 & 0.210903 & 32.33997 \\
\hline Median & 0.166700 & 0.048750 & 9.535900 & 5.735100 & 0.215600 & 32.25520 \\
\hline Maximum & 0.500000 & 0.075000 & 9.580600 & 14.74840 & 0.395900 & 34.95210 \\
\hline Minimum & 0.050000 & 0.037500 & 9.505700 & 2.713600 & 0.104800 & 30.12910 \\
\hline Std. Dev. & 0.154852 & 0.012414 & 0.025052 & 2.199606 & 0.062932 & 0.802967 \\
\hline$N$ & 132 & 132 & 132 & 132 & 132 & 132 \\
\hline
\end{tabular}

Source: EViews Data Processing 12

The results of the analysis were obtained from descriptive statistics in 20152020 with the amount of observation data as many as 132 series of bonds. Some explanations of the results of statistical calculations are described as follows:

a) Yield to Maturity (YTM)

Based on table 2, Yield to Maturity (YTM) has a minimum value of 0.050000 derived from PT. Bank Tabungan Negara (Persero) Tbk series of BBTN02DCN1 bonds in 2015. And the maximum Yield to Maturity value of 0.500000 comes from PT. Bank UOB Indonesia Tbk series of bonds BBIA01SB and BBIA01C, PT. Bank Rakyat Indonesia (Persero) Tbk series of bonds BBRI01CCN1, PT. Bank Tabungan Negara (Persero) Tbk series of bonds BBTN14, BBTN15 and BBTN02BCN1, PT. Indo Eximbank Tbk bond series BEXI02BCN4, BEXI02CCN5 and BEXI02CCN6, PT. Bank CIMB Niaga Tbk BNGA02SB bond series, PT. Bank Maybank Indonesia Tbk bnii02SBCN1 bond series, PT. Bank Permata Tbk BVIC03SB bond series, PT. 
Bank Mayapada International series obliagasi MAYA03SB and MAYA04SB. In 2019 and 2020, respectively.

The mean value is 0.215159 . This shows that the interest rate or the amount of yield expected by investors until maturity is $21.51 \%$ of the amount of the nominal value of bond emissions. The average value of yield to maturity indicates that investment through corporate bonds is sufficient to provide a high prospect of return. A standard deviation smaller than the mean value indicates that the data is homogeneous and has a low deviation rate.

b) Interest Rate (Rate)

Based on table 2, interest rates have a minimum value of 0.037500 for all series of bonds in 2020, the value shows that in $2020 \mathrm{BI}$ interest rates have decreased or low value, this is intended so that banks are more free to increase credit growth. While the maximum value is 0.075000 for all series of bonds in 2015 , the value shows that in 2020 BI interest rates have increased or high value. 2015 market interest rates increased as the economic cycle changes, such as growth rates and inflation. The average or mean value of 0.052083 with a standard deviation of 0.012414. A standard deviation smaller than the mean value indicates that the data is homogeneous and has a low deviation rate. This shows that the average liquidity in the community increases while the liquidity of banks decreases.

c) Exchange Rate (Exchange Rate)

Based on table 2, the exchange rate (exchange rate) has a minimum value of 9.505700 or rp. 13436 per US Dollar (USD) for all series of bonds in 2016. The highest exchange rate (maximum) is 9.580600 or rp.14,481 per US Dollar (USD) for all bond series in 2018. The mean average value is 9.537733 with a standard deviation of 0.025052 . A standard deviation smaller than the mean value indicates that the data is homogeneous and has a low deviation rate. This shows that rupiah pressure is influenced by the decline in the Rupiah exchange rate on Indonesia's net export performance. High forex demand was affected by the increase in imports in 2018 in line with rising domestic demand. This domestic demand condition caused net foreign exchange demand to increase and put pressure on the rupiah in 2018 .

d) Leverage (DER)

Based on table 2, leverage (DER) has a minimum value of 2.713600 which is bearasal from PT. Indoexim Bank Tbk series of bonds BEXI02BCN4, BEXI02CCN5 and BEXI02CCN6 in 2020, the value shows that the company has debts of 2.713600 times derived from equity owned by the company. While the maximum leverage value of 14.74840 comes from PT. Bank Bukopin Tbk series of BBKP02SBCN1 bonds in 2017, the value shows that the company has debt of 14.74840 times that comes from the company's equity. Leverage has an average or mean of 6.184280 with a standard deviation of 2.199606. A standard deviation smaller than the mean value indicates that the data is 
homogeneous and has a low deviation rate. This shows that the average bond issuer sample company has a debt of 6.184280 times the company's own capital (equity).

e) Liquidity (CR)

Based on table 2, liquidity (CR) has a minimum value of 0.104800 derived from PT. Bank Victoria Internasional Tbk. BVIC03SB Bond Series in 2019. The value indicates that the company has 0.104800 times the current assets in meeting long-term obligations Nutshell. While the maximum liquidity value of 0.395900 comes from PT. Indoexim Bank Tbk series of bonds BEXI02BCN4, BEXI02CCN5 and BEXI02CCN6 in 2019. The value indicates that the company has 0.395900 times the current assets in meeting its shortterm obligations. Liquidity has an average or mean of 0.210903 with a standard deviation of 0.215600 . A standard deviation smaller than the mean value indicates that the data is homogeneous and has a low deviation rate. This shows that the average bond issuer sample company has 0.210903 times current assets in meeting short-term obligations owned by the company.

f) Company Size (Size)

Based on table 2, the size of the company (Size) has a minimum value of 30.12910 derived from PT. Bank Capital Indonesia Tbk series of BACA01SB bonds in 2015 with total assets owned by PT. Bank Capital Indonesia Tbk amounted to Rp.12.16 Trillion. While the maximum value of the company size (size) of 34.95210 comes from PT. Bank Rakyat Indonesia (Persero) Tbk BBRI01CCN1 bond series in 2020 with total assets held rp. 1,512 trillion. The size of the company has an average or mean of 32.33997 with a standard deviation of 0.802967. A standard deviation smaller than the mean value indicates that the data is homogeneous and has a low deviation rate. This shows the average value of total assets, so the companies in the banking sector included in this study sample are classified as large companies, with an average value of total assets of Rp. 165 trillion.

\section{Inferential Statistics}

In the inferential test explain how to see the influence of independent variables namely Interest Rate (IRATE), Exchange Rate (KURS), Leverage (DER), Liquidity (CR) and Company Size (SIZE) on dependent variables namely Yield To Maturity (YTM).

\section{Selection of Panel Data Regression Estimation Model}

In testing the panel data regression estimation method, the selection of models used is based on three models, namely Common Effect Model (CEM), Fixed Effect Model (FEM) and Random Effect Model (REM). Here are the results of the model selection conducted:

\section{Common Effect Model (CEM)}

Here are the results of the Common Effect Model (CEM) approach method data: 
Table 3

Common Effect Model Panel Data Regression Results

\begin{tabular}{|c|c|c|c|c|}
\hline Variable & Coefficient & Std. Error & t-Statistic & Prob. \\
\hline $\mathrm{C}$ & -27.88904 & 4.014906 & -6.946374 & 0.0000 \\
\hline IRATE & 87132 & 67655 & -7.24 & 0.0000 \\
\hline KURS & 77 & 73 & & .0000 \\
\hline$D E R$ & -0.004077 & 72 & -0.7 & 0.4657 \\
\hline$C R$ & -0.2 & 0.1 & & 0.1599 \\
\hline SIZE & 0.01 & 0.014374 & 1.163796 & 0.2467 \\
\hline R-squared & 0.446269 & \multicolumn{2}{|c|}{ Mean dependent var } & 0.215159 \\
\hline Adjusted R-sq & 0.424295 & \multicolumn{2}{|c|}{ S.D. dependent var } & 0.154852 \\
\hline S.E. of regres & 4 & \multicolumn{2}{|c|}{ Akaike info criterion } & -1.400462 \\
\hline Sum squared re & 1.73 & \multicolumn{2}{|c|}{ Schwarz criterion } & -1.269426 \\
\hline Log likelihood & 98.43 & \multicolumn{2}{|c|}{ Hannan-Quinn criter. } & -1.347215 \\
\hline F-statistic & 20.30945 & \multirow{2}{*}{\multicolumn{2}{|c|}{ Durbin-Watson stat }} & 1.195589 \\
\hline Prob (F-statistic) & 0.000000 & & & \\
\hline
\end{tabular}

Source: EViews Data Processing 12

Based on table 3. showing the value of prob (F-statistic) IRATE and KURS of $0.000000<$ the value of $\alpha(0.05)$ means that IRATE and KURS affect YTM. Adjusted R-square (R2) results of this model of 0.424295 show that $42.42 \%$ of the YTM variation can be explained by changes in variables IRATE, KURS, DER, $\mathrm{CR}$ and SIZE while the rest is explained by other variables outside the research variables.

\section{Fixed Efffect Model (FEM)}

Here are the results of the data process for the Fixed Efffect Model (FEM) approach method:

Table 4

Fixed Panel Data Regression Results Efffect Model

\begin{tabular}{crrrr}
\hline Variable & Coefficient & Std. Error & t-Statistic & Prob. \\
\hline C & -22.75555 & 3.895705 & -5.841190 & 0.0000 \\
\hline IRATE & -4.111630 & 1.106190 & -3.716931 & 0.0003 \\
\hline KURS & 1.934255 & 0.473667 & 4.083576 & 0.0001 \\
\hline DER & -0.036730 & 0.014133 & -2.598831 & 0.0107 \\
\hline CR & 0.290811 & 0.235519 & 1.234770 & 0.2197 \\
\hline SIZE & 0.151585 & 0.055114 & 2.750397 & 0.0070 \\
\hline
\end{tabular}

Effects Specificat

\begin{tabular}{lllr}
\hline R-squared & 0.651594 & Mean dependent var & 0.215159 \\
\hline Adjusted R-squared & 0.565322 & S.D. dependent var & 0.154852 \\
\hline S.E. of regression & 0.102094 & Akaike info criterion & -1.545591 \\
\hline Sum squared resid & 1.094440 & Schwarz criterion & -0.955927 \\
\hline Log likelihood & 129.0090 & Hannan-Quinn criter. & -1.305978 \\
\hline F-statistic & 7.552787 & Durbin-Watson stat & 1.395748 \\
\hline Prob (F-statistic) & 0.000000 & & \\
\hline
\end{tabular}

Source: EViews Data Processing 12 
Based on table 4. showing the prob (F-statistic) values IRATE, KURS, DER, and SIZE of $0.00000<0.05$ means it affects YTM. An Adjusted R-square $\left(\mathrm{R}^{2}\right)$ value of 0.565322 indicates that $56.53 \%$ of the YTM variation can be explained by changes in the variables IRATE, KURS, DER, CR and SIZE while the rest is explained by other variables outside the research variables.

\section{Random Efffect Model (REM)}

Table 5

Random Panel Data Regression Results Efffect Model

\begin{tabular}{|c|c|c|c|c|}
\hline Variable & Coefficient & Std. Error & t-Statistic & Prob. \\
\hline $\mathrm{C}$ & -27.46147 & 3.533430 & -7.771902 & 0.0000 \\
\hline IRATE & -6.299764 & 0.774591 & -8.133022 & 0.0000 \\
\hline KURS & 2.856780 & 0.373465 & 7.649395 & 0.0000 \\
\hline DER & -0.003773 & 0.006496 & -0.580750 & 0.5624 \\
\hline $\mathrm{CR}$ & -0.070054 & 0.184124 & -0.380471 & 0.7042 \\
\hline SIZE & 0.024602 & 0.017950 & 1.370584 & 0.1729 \\
\hline \multicolumn{5}{|c|}{ Effects Specification } \\
\hline & & & S.D. & Rho \\
\hline Cross-section random & & & 0.050111 & 0.1941 \\
\hline Idiosyncratic random & & & 0.102094 & 0.8059 \\
\hline \multicolumn{5}{|c|}{ Weighted Statistics } \\
\hline R-squared & 0.488964 & & Mean dependent var & 0.137587 \\
\hline Adjusted R-squared & 0.468684 & & S.D. dependent var & 0.145921 \\
\hline S.E. of regression & 0.106364 & & Sum squared resid & 1.425467 \\
\hline F-statistic & 24.11155 & & Durbin-Watson stat & 1.356021 \\
\hline Prob(F-statistic) & 0.000000 & & & \\
\hline \multicolumn{5}{|c|}{ Unweighted Statistics } \\
\hline R-squared & 0.440064 & Mean depen & ident var & 0.215159 \\
\hline Sum squared resid & 1.758914 & Durbin-Wat & tson stat & 1.098952 \\
\hline
\end{tabular}

Based on table 5. Obtained prob (F-statistic) IRATE and KURS value of $0.00000<0.05$ means that it affects YTM. An Adjusted R-square $\left(\mathrm{R}^{2}\right)$ value of 0.468684 indicates that $46.86 \%$ of the YTM variation can be explained by changes in the variables IRATE, KURS, DER, CR and SIZE while the rest is explained by other variables outside the research variables.

\section{Selection of Panel Data Regression Model}

In the regression of panel data, the results of the model selection were carried out using three tests, namely the Chow Test, Hausman Test and Lagrange Multiplier Test (LM). Here's the panel data regression model:

1) Chow Test

Chow tests are conducted to find out if the Common Effect Model or fixed effect model is more appropriate. In this test is done with the following hypothesis:

$\mathrm{H}_{\mathrm{o}}$ : Common Effect Model 


\section{$\mathrm{H}_{1}$ : Fixed Effect Model}

The basis of decision making is:

a) If $\mathrm{H}_{0}$ is accepted, then the CEM model is appropriate. $\mathrm{H}_{0}$ is accepted if the probability value $>0.05$.

b) If the $\mathrm{H}_{0}$ is rejected, then the FEM model is appropriate. $\mathrm{H}_{0}$ is rejected if the probability value $<0.05$.

Table 6

Chow Test Results

\begin{tabular}{lcrr}
\hline Effects Test & Statistic & d.f. & Prob. \\
\hline Cross-section F & 2.946633 & $(21,105)$ & 0.0001 \\
\hline Cross-section Chi-square & 61.156977 & 21 & 0.0000 \\
\hline
\end{tabular}

Source: EViews Data Processing 12

Based on table 6. The Chi-square Cross-section probability value of 0.0000 $<(0.05)$. So the $\mathrm{H}_{0}$ was rejected then the FEM model was the appropriate model. Then continue the Hausman Test..

2) Hausman Test

Hausman as a statistical test to choose whether the Fixed Effect Model and Random Effect Model are most appropriately used. In this test is done with the following hypotheses:

H0: Random Effect Model

H1: Fixed Effect Model

The basis of decision making is:

a) If the $\mathrm{H}_{0}$ is accepted, then the REM model is appropriate. $\mathrm{H}_{0}$ is accepted if the probability value $>0.05$.

b) If the $\mathrm{H}_{0}$ is rejected, then the FEM model is appropriate. $\mathrm{H}_{0}$ is rejected if the probability value $<0.05$.

Table 7

Hausman Test Results

\begin{tabular}{crrr}
\hline Test Summary & Chi-Sq.Statistic & Chi-Sq. d.f. & Prob. \\
\hline Cross-section random & 0.000000 & 5 & 1.0000 \\
\hline
\end{tabular}

Source: EViews Data Processing 12

Based on table 7. Cross-section random probability value of 1,000>0.05. So that $\mathrm{H} 0$ is accepted then the REM model is the appropriate.

3) Lagrange Multiplier (LM) Test

The Lagrange Multiplier test is done to find out if the Random Effect Model model is better than the Common Effect Model model. In this test is done with hypotheses:

H0: Common Effect Model

H1: Random Effect Model 
The basis of decision making is :

a) If the $\mathrm{H}_{0}$ is accepted, then the REM model is appropriate. $\mathrm{H}_{0}$ is accepted if the value of Both Breusch-Pagan $<0.05$.

b) If $\mathrm{H}_{0}$ is rejected, then the CEM model is appropriate. $\mathrm{H}_{0}$ rejected if BreuschPagan $>0.05$.

Table 8

Lagrange Multiplier

\begin{tabular}{lccc}
\hline & \multicolumn{2}{c}{ Cross-section Test Hypothesis Time } & Both \\
\hline Breusch-Pagan & 7.628480 & 212.9731 & 220.6016 \\
\hline Honda & $(0.0057)$ & $(0.0000)$ & $(0.0000)$ \\
\hline King-Wu & 2.761970 & 14.59360 & 12.27224 \\
\hline & $(0.0029)$ & $(0.0000)$ & $(0.0000)$ \\
\hline Standardized Honda & 2.761970 & 14.59360 & 14.32672 \\
\hline & $(0.0029)$ & $(0.0000)$ & $(0.0000)$ \\
\hline Standardized King-Wu & 3.289773 & 21.08137 & 11.28628 \\
\hline & $(0.0005)$ & $(0.0000)$ & $(0.0000)$ \\
\hline Gourieroux, et al. & 3.289773 & 21.08137 & 15.92230 \\
\hline & $(0.0005)$ & $(0.0000)$ & $(0.0000)$ \\
\hline
\end{tabular}

Source: EViews Data Processing 12

Based on table 8. Cross-section random probability value of Prob. Both Breusch-Pagan of 0.0000 or $<0.05$ So that $\mathrm{H}_{0}$ is accepted then rem model is the appropriate model.

Based on the results of the test of the three panel data regression models, it can be concluded that the Random Effect Model is suitable in determining the effect of interest rates, exchange rates, leverage, liquidity and the size of the company on yield to maturity. Here is the conclusion table of the panel data regression model test results:

Table 9

Panel Data Regression Mode Testing Conclusion

\begin{tabular}{llll}
\hline No & Type & \multicolumn{1}{c}{ Testing } & Result \\
\hline 1 & Uji Chow & $\begin{array}{l}\text { Common Effect Model vs Fixed Effect } \\
\text { Model }\end{array}$ & Fixed Effect Model \\
\hline 2 & Uji Hausman & $\begin{array}{l}\text { Fixed Effect Model vs Random Effect } \\
\text { Model }\end{array}$ & Random Effect Model \\
\hline 3 & $\begin{array}{l}\text { Uji Lagrange } \\
\text { Multiplier }\end{array}$ & $\begin{array}{l}\text { Common Effect Model vs Random } \\
\text { Effect Model }\end{array}$ & Random Effect Model \\
\hline
\end{tabular}

Source: processed by researchers (2021)

\section{Panel Data Regression Model Analysis}

Testing of hypotheses is done with the panel data regression method. The panel data regression method is used to determine the effect of independent variables on dependents. The regression equation of panel data is as follows: 


\begin{tabular}{|c|c|c|c|c|}
\hline \multicolumn{5}{|c|}{$\begin{array}{c}\text { Table } 10 \\
\text { Metode Rendom Effect Model }\end{array}$} \\
\hline Variable & Coefficient & Std. Error & t-Statistic & Prob. \\
\hline $\mathrm{C}$ & -27.46147 & 3.533430 & -7.771902 & 0.0000 \\
\hline IRATE & -6.299764 & 0.774591 & -8.133022 & 0.0000 \\
\hline KURS & 2.856780 & 0.373465 & 7.649395 & 0.0000 \\
\hline DER & -0.003773 & 0.006496 & -0.580750 & 0.5624 \\
\hline $\mathrm{CR}$ & -0.070054 & 0.184124 & -0.380471 & 0.7042 \\
\hline SIZE & 0.024602 & 0.017950 & 1.370584 & 0.1729 \\
\hline \multicolumn{5}{|c|}{ Effects Specification } \\
\hline & & & S.D. & Rho \\
\hline Cross-section random & & & 0.050111 & 0.1941 \\
\hline Idiosyncratic random & & & 0.102094 & 0.8059 \\
\hline \multicolumn{5}{|c|}{ Weighted Statistics } \\
\hline R-squared & 0.488964 & \multicolumn{2}{|c|}{ Mean dependent var } & 0.137587 \\
\hline Adjusted R-squared & 0.468684 & \multicolumn{2}{|c|}{ S.D. dependent var } & 0.145921 \\
\hline S.E. of regression & 0.106364 & \multicolumn{2}{|c|}{ Sum squared resid } & 1.425467 \\
\hline F-statistic & 24.11155 & \multicolumn{2}{|c|}{ Durbin-Watson stat } & 1.356021 \\
\hline Prob(F-statistic) & 0.000000 & & & \\
\hline \multicolumn{5}{|c|}{ Unweighted Statistics } \\
\hline R-squared & 0.440064 & \multirow{2}{*}{\multicolumn{2}{|c|}{$\begin{array}{l}\text { Mean dependent var } \\
\text { Durbin-Watson stat }\end{array}$}} & 0.215159 \\
\hline Sum squared resid & 1.758914 & & & 1.098952 \\
\hline
\end{tabular}

Based on Table 10. column coefficients obtained value $\mathrm{C}=-27.46147$ interest rate variable value (IRATE) $=-6.299764$, exchange rate (Exchange Rate) $=2.856780$, Leverage value $(\mathrm{DER})=-0.003773$, variable value Liquidity $(\mathrm{CR})=-$ 0.070054 , and variable value Company Size $($ SIZE $)=0.024602$.

The panel data regression equation model can be formulated as follows:

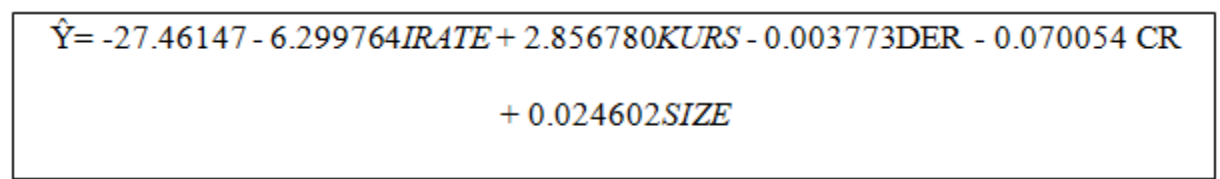

Based on the equation above, the free variable regression coefficient mark (interest rate, exchange rate, leverage, likudity and company size) indicates the direction of the relationship with yield to maturity. so that the above panel data equation can be explained as follows:

1) The constant value of -27.46147 , means that if the variables of Interest Rate, Exchange Rate, Leverage, Likudity and Company Size do not change or are constant then the Yield To Maturity of bonds on the Indonesia Stock Exchange 
is -27.46147 . It can be concluded that constants have the opposite relationship to Yield To Maturity.

2) IRATE $\left(X_{1}\right)$ is a regression value of interest rate variables that have a negative relationship of -6.299764 , meaning that if the interest rate variable increases by $1 \%$, then the change in Yield To Maturity will decrease by -6.299764 assuming that other free variables do not change or are constant. It can be concluded that the Interest Rate variable has the opposite relationship to yield to maturity.

3) KURS $\left(X_{2}\right)$ is a regression value of exchange rate variables that have a positive relationship of 2.856780 , meaning that if the exchange rate variable increases by $1 \%$, then the yield to maturity change will increase by 2.856780 assuming that other free variables do not change or are constant. It can be concluded that the Exchange Rate variable has a relationship that is in line with Yield To Maturity.

4) DER $\left(X_{3}\right)$ is a regression value of leverage variables that have a negative relationship of -0.003773 , meaning that if the Leverage variable increases by $1 \%$, then the yield to maturity change will decrease by -0.003773 assuming that other free variables do not change or are constant. It can be concluded that leverage variables have the opposite relationship to Yield To Maturity.

5) $\mathrm{CR}\left(\mathrm{X}_{4}\right)$ is a liquidity variable regression value that has a negative relationship of -0.070054 meaning that if the Liquidity variable increases by $1 \%$, then the yield to maturity change will decrease by -0.070054 assuming that other free variables do not change or are constant. It can be concluded that liquidity variables have the opposite relationship to yield to maturity.

6) SIZE $\left(\mathrm{X}_{5}\right)$ is a regression value of the Company Size variable that has a positive relationship of 0.024602 meaning that if the Company Size variable increases by $1 \%$, then the yield to maturity change will increase by 0.024602 assuming that other free variables do not change or are constant. It can be concluded that the Company's Size variable has a relationship that is in line with Yield to Maturity.

\section{Classic Assumption Test}

According to (Gujarati, 2012) the random effect panel model uses the Generalized Least Square (GLS) method, while the Common Effect model and fixed effect panel model use ordinary least square (OLS). One of the advantages of the GLS method is that it does not We need to meet classical assumptions. So, if the regression model uses the Random Effect Model then There is no need to test classical assumptions. Conversely, if the Common Effect Model or Fixed Effect Model regression model is used, it is necessary to test classical assumptions.

According to (Gujarati, 2012) there is very little chance of multicollinearity on panel data that researchers can simply perform autocorrelation tests and heterocorticity tests. 


\section{Hypothesis Test}

Hypothesis testing can be seen based on simultaneous test (Test F) Partial Test (Test $\mathrm{t}$ ) and coefficient of determination (R2). As for the results of the model conformity test as follows:

1) Simultaneous Test (Test F)

The $\mathrm{F}$ test is performed to test the feasibility of the model, whether all independent variables have an overall effect on dependent variables. The level of significance set in the study was $\alpha=0.05$. The basis of decision making is:

a) If the $\mathrm{H}_{0}$ is accepted, then the model does not fit. $\mathrm{H}_{0}$ is accepted if the probability value (F-statistic) $>0.05$.

b) If the $\mathrm{H}_{0}$ is rejected, then the model is suitable. $\mathrm{H}_{0}$ is rejected if the probability value $(\mathrm{F}-$ statistic $)<0.05$.

Table 11

Simultaneous Test Results (Test F)

\begin{tabular}{crrrc}
\hline Variable & Coefficient & Std. Error & t-Statistic & Prob. \\
\hline $\mathrm{C}$ & -27.46147 & 3.533430 & -7.771902 & 0.0000 \\
\hline IRATE & -6.299764 & 0.774591 & -8.133022 & 0.0000 \\
\hline KURS & 2.856780 & 0.373465 & 7.649395 & 0.0000 \\
\hline DER & -0.003773 & 0.006496 & -0.580750 & 0.5624 \\
\hline CR & -0.070054 & 0.184124 & -0.380471 & 0.7042 \\
\hline SIZE & 0.024602 & 0.017950 & 1.370584 & 0.1729 \\
\hline & Effects Specification & & \\
\hline Cross-section random & & & S.D. & Rho \\
\hline Idiosyncratic random & & 0.050111 & 0.1941 \\
\hline
\end{tabular}

\begin{tabular}{llll}
\hline \multicolumn{4}{l}{ Weighted Statistics } \\
\hline R-squared & 0.488964 & Mean dependent var & 0.137587 \\
\hline Adjusted R-squared & 0.468684 & S.D. dependent var & 0.145921 \\
\hline S.E. of regression & 0.106364 & Sum squared resid & 1.425467 \\
\hline F-statistic & 24.11155 & Durbin-Watson stat & 1.356021 \\
\hline Prob (F-statistic) & 0.000000 & & \\
\hline
\end{tabular}

Source: EViews Data Processing 12

Based on table 11. Test output F obtained a probability value (F- statistic) of $0.0000<0.05$. So that $\mathrm{H} 0$ is accepted, it is noted that together the Variables of Interest Rates, Exchange Rates, Leverage, Liquidity and Company Size affect the Variable Yield To Maturity.

2) Partial Test (Test t)

The $\mathrm{t}$ test is performed to show how far the influence of one individually independent variable in explaining the variation of dependent variables.

The basis of decision making is: 
a) If $\mathrm{H}_{0}$ is accepted, then the coefficient is not of significance to the independent variable. $\mathrm{H}_{0}$ is accepted if the probability value (t-statistic) variable $\mathrm{X}_{1}$ (interest rate), variable $\mathrm{X}_{2}$ (Exchange rate), variable $\mathrm{X}_{3}$ (Leverage), variable $\mathrm{X}_{4}$ (Liquidity), and variable $\mathrm{X}_{5}$ (Company Size) > 0.05 .

b) If $\mathrm{H}_{0}$ is rejected, then the coefficient is significant against the independent variable. $\mathrm{H}_{0}$ is rejected if the probability value (t-statistic) $\mathrm{X}_{1}$ (interest rate), variable $\mathrm{X}_{2}$ (Exchange rate), variable $\mathrm{X}_{3}$ (Leverage), variable $\mathrm{X}_{4}$ (Liquidity), and variable $\mathrm{X}_{5}$ (Company Size) $<0.05$.

Table 12

Partial Test Results (Test t)

\begin{tabular}{crrrl}
\hline Variable & Coefficient & Std. Error & t-Statistic & Prob. \\
\hline C & -27.46147 & 3.533430 & -7.771902 & 0.0000 \\
\hline IRATE & -6.299764 & 0.774591 & -8.133022 & 0.0000 \\
\hline KURS & 2.856780 & 0.373465 & 7.649395 & 0.0000 \\
\hline DER & -0.003773 & 0.006496 & -0.580750 & 0.5624 \\
\hline CR & -0.070054 & 0.184124 & -0.380471 & 0.7042 \\
\hline SIZE & 0.024602 & 0.017950 & 1.370584 & 0.1729 \\
\hline
\end{tabular}

Source: EViews Data Processing 12

Based on table 12. test output result t obtained:

1. Interest

The interest rate variable $\left(\mathrm{X}_{1}\right)$ indicates a probability value of $0.0000<0.05$, so that $\mathrm{H}_{0}$ is rejected then it can be concluded that the interest rate variable has a significant negative effect on yield to maturity.

2. Exchange rate

The exchange rate variable $\left(\mathrm{X}_{2}\right)$ indicates a probability value of $0.0000<0.05$, so that $\mathrm{H} 0$ is rejected then it can be concluded that the exchange rate variable has a significant positive effect on yield to maturity.

3. Leverage

Leverage variable $\left(\mathrm{X}_{3}\right)$ shows a probability value of $0.5624>0.05$, so that $\mathrm{H}_{0}$ is rejected then it can be concluded that the leverage variable has no effect on yield to maturity.

\section{Liquidity}

Liquidity Variable $\left(\mathrm{X}_{4}\right)$ indicates a probability value of $0.7042>$ 0.05 , so that $\mathrm{H}_{0}$ is rejected then it can be concluded that liquidity variables have no effect on yield to maturity.

5. Company Size

The Company Size Variable $\left(\mathrm{X}_{5}\right)$ indicates a probability value of $0.1729>0.05$, so that $\mathrm{H}_{0}$ is rejected then it can be concluded that the Company Size variable has no effect on yield to maturity..

3) Coefficient of Determination $\left(R^{2}\right)$ 
Coefficient of determination $\left(\mathrm{R}^{2}\right)$ Measure how far the model's ability to explain variations in its dependent variables. If $\mathrm{R} 2$ gets closer to number 1 then the match will be better.

Table 13

Coefficient of Determination Results $\left(\mathbf{R}^{2}\right)$

\begin{tabular}{ccccc}
\hline Variable & Coefficient & Std. Error & t-Statistic & Prob. \\
\hline C & -27.46147 & 3.533430 & -7.771902 & 0.0000 \\
\hline IRATE & -6.299764 & 0.774591 & -8.133022 & 0.0000 \\
\hline KURS & 2.856780 & 0.373465 & 7.649395 & 0.0000 \\
\hline DER & -0.003773 & 0.006496 & -0.580750 & 0.5624 \\
\hline CR & -0.070054 & 0.184124 & -0.380471 & 0.7042 \\
\hline SIZE & 0.024602 & 0.017950 & 1.370584 & 0.1729 \\
\hline \multicolumn{5}{c}{ Sffects Specification } \\
\hline Cross-section random \\
\hline Idiosyncratic random \\
\hline \multicolumn{5}{c}{ R.D. } \\
\hline R-squared & Weighted Statistics & Rho \\
\hline Adjusted R-squared & 0.488964 & Mean dependent var & 0.137587 \\
\hline S.E. of regression & 0.468684 & S.D. dependent var & 0.145921 \\
\hline F-statistic & 0.106364 & Sum squared resid & 1.425467 \\
\hline Prob(F-statistic) & 24.11155 & Durbin-Watson stat & 1.356021 \\
\hline
\end{tabular}

\begin{tabular}{lcll}
\hline \hline & Unweighted Statistics & \\
\hline R-squared & 0.440064 & Mean dependent var & 0.215159 \\
\hline Sum squared resid & 1.758914 & Durbin-Watson stat & 1.098952 \\
\hline
\end{tabular}

Source: EViews Data Processing 12

Based on table 13. The output result of the coefficient of determination obtained the Adjusted R-Squred value of 0.468684 . This means that together the variables of Interest Rates, Exchange Rates, Leverage, Liquidity and Company Size affect the Variable Yield To Maturity by $46.8684 \%$, While the remaining $53.1316 \%$ were affected by fakor which was not included in the study.

\section{B. Discussion}

\section{Effect of Interest Rates on Yield to Maturity}

The results of the $t$ test showed that interest rates projected with IRATE partially negatively negatively affected the yield to Maturiry. Thus this yield is in line with the hypothetical statement made earlier that interest rates are suspected to have a negative effect on YTM bonds.

The higher the forecast (sensitivity) of future interest rates, the lower the forecast yield of bonds that lower the demand for these bonds. Falling bond demand when interest rates rise and bond prices fall result in funds received by issuers being less, so the yield offered by the company also becomes lower. 
Changes in BI rate depend on several aspects, namely the longer the maturity of a bond will be higher the sensitivity of bond prices to BI rate (Yusniar \& Hadi, 2021). The lower the coupon rate, the higher the price sensitivity to changes in BI rate. With demikin the higher the price of a bond, the lower the yield to maturity offered.

The results of this study are in line with the research of (Saputra \& Prasetiono, 2013), (Ernawati, 2019) and Friday E and (Nkwede, 2020) stated that interest rates negatively affect yield to maturity bonds. The higher the interest rate, the yield to maturity of bonds will decrease.

This research is related to signalling theory, that by providing a signal, the sender (owner of information) seeks to provide relevant pieces of information utilized by the recipient. According to (Fahmi, 2015). Signalling theory provides information about the rise and fall of Bank Indonesia's benchmark interest rate or so-called BI-7 Day Reverse Repo Rate (BI7DRR), so it will affect investor decisions. Signalling theory describes the relationship with the issue of information disclosure, if the company reveals bad news then the market will give a negative reaction and this is consistent with the efficient market hypothesis (Lestari, 2016).

\section{Effect of Exchange Rates on Yield to Maturity}

The results of the $t$ test showed that the exchange rate projected with the Exchange Rate partially had a significant positive effect on the Yield to Maturiry. Thus this result is in line with the hypothetical statement made earlier that the exchange rate is suspected to have a positive effect on YTM bonds.

When the rupiah exchange rate against too high, it can be said that the rupiah currency is depreciating, meaning that the rupiah currency is weakening against the USD currency. This has an impact on the capital costs that the company must pay to be large and will increase the risk of the company not being able to pay off its debts or in other words the company has a high risk of default, so the company will offer a higher yield so that investors are interested in investing in bonds that are offered (Aulia and Miyasto, 2019). When the exchange rate depreciates against the U.S. Dollar it will make investors want higher returns. For investors depreciation (rupiah weakened). This indicates that indonesia's economic prospects are experiencing ugliness. When the value of the rupiah appreciates, investors will switch investments into the money market such as the foreign exchange market. Of course, this will result in a decrease in demand for bonds. When the demand for bonds falls, the bond issuer must attract investors again by increasing the yield on the bond, when the exchange rate depreciates then the bond yield will increase and vice versa. In other words, the exchange rate has a positive effect on the yield to maturity of bonds (Wibisono, 2010).

According to research (Purwadi, 2017), (Ernawati, 2019) and Paramita and Pangestuti (2016) stated that exchange rates or exchange rates have a positive 
effect on bond yields. The higher the exchange rate, the yield to maturity of bonds also increases.

This research is related to signal theory. With the rise and fall of the dollar rate, interest rates will rise because Bank Indonesia will hold the rupiah so that consequently inflation will increase. At that time investors rely on signals from the company, whether the circumstances affect the performance of the company and its stock price. Signaling theory explains why companies have the urge to provide financial statement information to external parties, because there is an information asymmetry between companies and outside parties. The company (agent) knows more about the company and the prospects to come than outsiders (investors, creditors). The lack of outside information about the company causes them to protect themselves by providing low prices for companies. One way to reduce asymmetry information is to provide.

\section{Leverage on Yield to Maturity}

The results of the $t$ test showed that the leverage projected with DER partially had no effect on yield to maturiry. This result contradicts previously made hypothetical assertions that leverage is thought to have a negative effect on YTM bonds.

The increase in the leverage ratio does not affect the increase in yield to maturity of bonds, which means that the leverage ratio is not factored into the high determining yield to maturity of the bond. This is because banking companies that are the object of this research include large companies that require high debt financing and tend to have large total assets. This shows that the company reaches a stage of maturity where in this stage the company has positive cash flow and has good stability and prospects over a relatively long period of time. When the company's business activities are at the maturity stage (mature), the Debt to Equity Ratio will reach its peak. At this stage, the company's profits are already quite high and the tax burden is also relatively high so that the company chooses an alternative funding through debt to reduce the amount of taxes (Oktavian et al., 2015).

Modigliani Miller's theory explains that the value of a company will increase as debt increases due to tax savings from debt interest payments, but this theory ignores the risk of debt where the greater the debt makes the company offer higher yields as compensation for the emergence of a large risk (risk of default). The results of this study support the research of (Situmorang, 2017), (Purnamawati, 2013), (Desnitasari \& Norita, 2014).

The results of this study are in line with the results of research conducted by (Oktavian et al., 2015) and (Situmorang, 2017) which states that if there is a decrease or increase in leverage it does not affect the high yield to maturity. But this study is not in line with the research of (Listiawati \& Paramita, 2018), (CheYahya et al., 2016) and (Hamid et al., 2019) which stated that leverage negatively affects yield to maturity. 
This research relates to Agency Theory, the agency relationship that occurs between principals and agents burden managers to account for the resources they manage. Companies that have a greater proportion of debt in their capital structure will have greater agency costs where the company has an obligation to meet the information needs of long-term creditors, so that the company will provide information more comprehensively.

\section{Effect of Liquidity on Yield to Maturity}

The results of the $t$ test showed that liquidity projected by the Current Ratio (CR) partially had no effect on yield to maturity. Thus this result contradicts the hypothetical statement made earlier that liquidity is suspected to have a positive effect on YTM bonds.

Liquidity has no effect on bond yield to maturity because in 2020 many investors are holding back and even selling their bonds to prevent losses that are too big (Indarsih, 2013). This can be seen in the highest frequency of corporate bond trading in the financial sector occurred in 2020. Can be seen in the following table:

Table 14

Frequency of Trading of Financial Sector

Corporate Bonds

\begin{tabular}{cc}
\hline Year & Frequency \\
\hline 2015 & 22,279 \\
\hline 2016 & 24,398 \\
\hline 2017 & 30,476 \\
\hline 2018 & 30,324 \\
\hline 2019 & 36,769 \\
\hline 2020 & 37,788 \\
\hline
\end{tabular}

Source: Financial Services Authority (OJK)

In table 14. In 2020, it was traded 37,788 times, up from the previous year 2019, which was only traded 36,769 times because in 2020 there was a health crisis and crisis. In table 4.14. In 2020, it was traded 37,788 times, up from the previous year 2019, which was only traded 36,769 times because in 2020 there was a health crisis and crisis.the global economy caused by COVID-19 so that Indonesia experienced an increase in inflation rate by 1.68 percent. (www.bi.go.id).

This phenomenon causes the number of withdrawals of funds by foreign investors, causing the frequency of Indonesian trading to increase. Based on the phenomenon that occurred in 2020 shows that the existence of extreme data from trading frequency that resulted in frequency data in 2020 is not able to describe the yield to maturity that investors hint but the high yield to maturity can be influenced by external factors such as inflation of a country (Indarsih, 2013).

The results of this study are in line with the results of research conducted by Susanti and Permana (2017), Noviana (2018), (Putri, 2013) and (Oktavian et al., 
2015), which stated that if there is a decrease or increase in liquidity it does not affect the high yield to maturity. But not in line with the research of (Ernawati, 2019) and (TRINH et al., 2020) states that liquidity has a positive influence on yield to maturity of bonds.

This research is related to the signal theory, which states that a good quality company will give a positive signal in the form of good information so that investors are expected to give confidence in investing bonds in the company. If the company is able to finance and pay off its short-term obligations properly then the company's potential to increase investor confidence in investing in bonds increases. In this study, the company's liquidity is expected to be able to be a means of predicting healthy company conditions.

\section{Effect of Company Size on Yield to Maturity}

The results of the t test showed that the size of the company projected with Size partially had no effect on yield to maturity. Thus this result contradicts the hypothetical statement made earlier that liquidity is suspected to have a positive effect on YTM bonds.

The results of this study stated that the size of the company had no effect on yield to maturity. The significant effect of the size of the company on yield to maturity indicates that total assets have not received attention from investors to see what the yield or yield to maturity of bonds is. According to (Situmorang, 2017) revealed the company's ability is still adequate to pay yields and better Indonesian market conditions become an attraction for investors, so the size of the company is not the most important factor. Investors are more considerate of other factors in bond returns.

The results of this study are in line with the results of research conducted by (Desnitasari \& Norita, 2014) and (Situmorang, 2017) which stated that the size of the company does not affect the high yield to maturity. But not in line with the research of (Yusniar \& Hadi, 2021), (Latif \& Marsoem, 2019) and Paramita and Pangestuti (2016) stated that the size of the company has a positive influence on yield to maturity bonds.

Variable size of the company shows yield has no effect on yield to maturity of bonds. The results of this study show that investors in the banking sector bond market do not consider the size of the company as a basis for investing. The company's ability to still adequately pay yields and better indonesian market conditions becomes an attraction for investors so that the Size of the Company is not the main factor.

With regard to Agency Theory, the agency relationship that occurs between the principal and the agent has burdened the manager to account for the resources he manages. The greater the total assets, the greater the resources managed by the company, the greater it means that the greater the activity of a business venture. With the magnitude of the activity of a business is expected to be greater the results of operations obtained. 


\section{Conclusion}

Based on the results of data testing using the EViews 12.0 program, the best model is the Random Effect Model, with a value of 0.468684 meaning that together variable interest rates, company value, leverage, liquidity and company size affect yield to maturity of $46.8684 \%$, while the remaining $53.1316 \%$ is influenced by other factors that are not included in the modeling of this study. Based on the results of data testing and discussion, it can be concluded: 1) Interest Rates have a significant negative effect on yield to maturity bonds in banking sector companies listed on the Indonesia Stock Exchange (IDX) for the period 2015-2020. 2) Exchange Rate has a significant positive effect on yield to maturity of bonds in banking sector companies listed on the Indonesia Stock Exchange (IDX) for the period 2015-2020. 3) Leverage has no effect on yield to maturity bonds in banking sector companies listed on the Indonesia Stock Exchange (IDX). 


\section{BIBLIOGRAFI}

Ahmad, G. N., \& Wahyudiani, W. (2019). Analisis Determinan Obligasi Korporasi. Jurnal Aplikasi Bisnis Dan Manajemen (JABM), 5(3), 361. Google Scholar

Che-Yahya, N., Abdul-Rahim, R., \& Mohd-Rashid, R. (2016). Determinants of corporate bond yield: the case of Malaysian bond market. International Journal of Business and Society, 17(2). Google Scholar

Desnitasari, I., \& Norita, N. (2014). Pengaruh Tingkat Suku Bunga, Peringkat Obligasi, Ukuran Perusahaan Dan Debt To Equity Ratio Terhadap Yield To Maturity Obligasi Korporasi Yang Terdaftar Di Bursa Efek Indonesia Periode 2010-2012. EProceedings of Management, 1(3). Google Scholar

Ernawati, L. (2019). Analisis Faktor-Faktor Yang Mempengaruhi Yield Spread Obligasi Konvensional Dan Obligasi Syariah Dengan Penerapan Error Correction Model (Ecm). Ncab. Google Scholar

Fabozzi, F., \& Modigliani, F. (1995). Capital markets instutions and instruments. New Jersey: Prentice Hall. Google Scholar

Fahmi, M. N. (2015). Pengaruh Audit Tenure, Opini Audit Tahun Sebelumnya, Dan Disclosure Terhadap Opini Audit Going Concern. Akuntabilitas, 8(3), 162-170. Google Scholar

Gujarati, D. N. (2012). Dasar-dasar ekonometrika Edisi 5 Buku 2 (Edisi 5). Salemba Empat. Google Scholar

Hamid, A. A., Siagian, A., Razak, A., \& Endri, E. (2019). Determinants of Bond Rating and its Implications to Corporate Bond Yield. International Journal of Engineering and Advanced Technology, 9(2), 195-200. Google Scholar

Latif, A., \& Marsoem, B. S. (2019). Analysis of Company Internal Factors on Yield to Maturity of Corporate Bonds Traded on the Indonesia Stock Exchange. International Journal of Innovative Science and Research Technology, 4(10), 3342. Google Scholar

Listiawati, L. N., \& Paramita, V. S. (2018). Pengaruh Tingkat Suku Bunga, Inflasi, Debt to Equity Ratio, dan Ukuran Perusahaan terhadap Yield Obligasi pada Perusahaan yang Terdaftar di Bursa Efek Indonesia Tahun 2010-2016. Jurnal Manajemen, 15(1), 33-51. Google Scholar

Megananda, D., Endri, E., Oemar, F., \& Husna, A. (2021). Determinants of Corporate Bond Yield: Empirical Evidence from Indonesia. The Journal of Asian Finance, Economics and Business, 8(3), 1135-1142. Google Scholar 
Nariman, A. (2016). Pengaruh faktor internal dan eksternal perusahaan terhadap yield to maturity obligasi korporasi yang terdaftar di Bursa Efek Indonesia. Jurnal Akuntansi, 20(2), 238-253. Google Scholar

Nelmida, N. (2018). Faktor-Faktor yang Menentukan Yield to Maturity Obligasi Korporasi. Seminar Nasional Sistem Informasi (SENASIF), 2(1), 1345-1357. Google Scholar

Nkwede, F. E. (2020). Macroeconomic determinants of bond market development: Evidence from Nigerian. International Journal of Development and Management Review, 15(1), 178-194. Google Scholar

Nkwede, F. E., Uguru, L. C., \& Nkwegu, L. C. (2016). Corporate Bond Market Development In Nigeria: Does Macroeconomic Factors Matter? Arabian Journal of Business and Management Review (Oman Chapter), 6(2), 25. Google Scholar

Oktavian, O., Haryetti, H., \& Sjahruddin, S. (2015). Pengaruh Tingkat Inflasi, Debt to Equity Ratio, Likuiditas Obligasi Dan Rating Obligasi Terhadap Yield Obligasi Kororasi Yang Terdaftar Di Bursa Efek Indonesia (Bei) Tahun 2009-2012. Riau University. Google Scholar

Purnamawati, I. G. A. (2013). Pengaruh Peringkat Obligasi, Tingkat Suku BungaSertifikat Bank Indonesia, Rasio Leverage, Ukuran Perusahaan Dan Umur Obligasi Pada Imbal Hasil Obligasi Korporasi Di Bursa Efek Indonesia. Vokasi: Jurnal Riset Akuntansi, 2(1). Google Scholar

Purwadi, A. T. (2017). Pengaruh Variabel Fundamental Makroekonomi Terhadap Yield Obligasi (Studi Kasus Obligasi Pemerintah Tenor 1 Tahun, 5 Tahun Dan 10 Tahun Periode 2010-2016). Jurnal Ilmiah Mahasiswa FEB, 6(1). Google Scholar

Putri, E. L. H. (2013). Pengaruh Risiko Likuiditas Perusahaan terhadap Yield Spread Obligasi. Jurnal Ekonomi Dan Bisnis Airlangga, 23(3). Google Scholar

Saputra, T. A., \& Prasetiono, P. (2013). Analisis Faktor-Faktor Yang Mempengaruhi Yield Obligasi Konvensional Di Indonesia (Studi Kasus Pada Perusahaan Listed di BEI). Fakultas Ekonomika dan Bisnis. Google Scholar

Situmorang, B. (2017). Pengaruh Peringkat Obligasi, Debt to Equity Ratio Dan Ukuran Perusahaan Terhadap Yield to Maturity Obligasi Korporasi Dengan Tingkat Suku Bunga SBI Sebagai Variabel Moderating. Jurnal Terapan Manajemen Dan Bisnis, 3(1), 195545. Google Scholar

Surya, B. A., \& Nasher, T. G. (2011). Analisis pengaruh tingkat suku bunga sbi, exchange rate, ukuran perusahaan, debt to equity ratio dan bond terhadap yield obligasi korporasi di indonesia. Jurnal Manajemen Teknologi, 10(2), 186-195. Google Scholar 
Trinh, Q. T., Nguyen, A. P., Nguyen, H. A., \& Ngo, P. T. (2020). Determinants of Vietnam government bond yield volatility: A GARCH approach. The Journal of Asian Finance, Economics, and Business, 7(7), 15-25. Google Scholar

Ulfah, H. K., Aprilliani, S., \& Adirestuty, F. (2019). Influence of Micro Economic and Macro Economic on Yield to Maturity of Ijarah Sukuk Corporation Year 20142017. KnE Social Sciences, 126-136. Google Scholar

Weniasti, A., \& Marsoem, B. S. (2019). The Effect of Bonds Rating, Profitability, Leverage, and Firm Size on Yield to Maturity Corporate Bonds. International Journal of Innovative Science and Research Technology, 4(8), 286-295. Google Scholar

Yani, J. A. (2017). Sugiyono. 2017. Metode Penelitian Kuantitatif, Kualitatif, Dan R\&D. Bandung: Alfabeta. Ferrari, JR, Jhonson, JL, \& McCown, WG (1995). Procrastination And Task Avoidance: Theory, Research \& Treatment. New York: Plenum Press. Yudistira P, Chandra. Diktat Ku. Google Scholar

Yusniar, M. W., \& Hadi, A. (2021). Pengaruh Tingkat Suku Bunga, Bond Rating, Ukuran Perusahaan, Debt To Equity Ratio (Der) Terhadap Yield To Maturity Obligasi Korporasi Di Bei Periode Tahun 2010-2012. Jwm (Jurnal Wawasan Manajemen), 6(3), 295-309. Google Scholar

Zulfa, M., \& Nahar, A. (2020). Faktor Determinan Yield Obligasi Perusahaan Korporasi. KRISNA: Kumpulan Riset Akuntansi, 11(2), 117-128. Google Scholar

\author{
Copyright holder: \\ Elfira Riani Syamsu, Endri (2022) \\ First publication right: \\ Jurnal Syntax Admiration
}

This article is licensed under: 